\title{
Inefficacy of albendazole sulphoxide and ivermectin for the treatment of bovine parasitic otitis caused by rhabditiform nematodes ${ }^{1}$
}

\author{
Guilherme G. Verocai ${ }^{2,3^{*}}$, Julio I. Fernandes ${ }^{2,4}$, Thaís R. Correia ${ }^{2}$, Raquel \\ M.P.S. Melo ${ }^{2}$, Pedro Afonso M. Alves ${ }^{5}$, Fabio B. Scott ${ }^{2}$ and Laerte Grisi ${ }^{2}$
}

\begin{abstract}
Verocai G.G., Fernandes J.I., Correia T.R., Melo R.M.P.S., Alves P.A.M., Scott F.B. \& Grisi L. 2009. Inefficacy of albendazole sulphoxide and ivermectin for the treatment of bovine parasitic otitis caused by rhabditiform nematodes. Pesquisa Veterinária Brasileira 29(11):910-912. Departamento de Parasitologia Animal, Instituto de Veterinária, Universidade Federal Rural do Rio de Janeiro, Seropédica, RJ 23890000, Brazil. E-mail: gverocai@gmail.com

The purpose of this study was to evaluate the efficacy of orally administered albendazole sulphoxide and pour-on ivermectin for the treatment of bovine parasitic otitis caused by rhabditiform nematodes. Eighteen Gyr cows presenting clinical otitis were divided in three groups with six animals each. The first one did not receive any treatment (control group). The second one was treated with $0.5 \%$ pour-on ivermectin, $500 \mu \mathrm{g} / \mathrm{kg}$ of body weight, and the third group was treated with oral $6 \%$ albendazole sulphoxide, at $6.0 \mathrm{mg} / \mathrm{kg}$. Both ear canals of each animal were reexamined on days 7 and 21 post treatment. The animals in the control group remained infected throughout the days of observation. Ivermectin treatment did not show effectiveness on days 7 or 21 post treatment. The albendazole sulphoxide treatment had an efficacy of 16.7 and $25 \%$ on days 7 and 21 , respectively. Further studies are required to assess an effective treatment for this parasitic disease, especially via alternative administration routes, because of its significant impact on Bos taurus indicus cattle breeding in Tropical and Subtropical Regions.
\end{abstract}

INDEX TERMS: Bovine parasitic otitis, rhabditiform nematodes, Rhabditis sp., treatment.

RESUMO.- [Ineficácia do sulfóxido de albendazole e da ivermectina no tratamento da otite parasitária bovina causada por nematóides rhabditiformes.] $O$ objetivo deste estudo foi avaliar a eficácia do sulfóxido de albendazol administrado oralmente e da ivermectina "pour-on" no tratamento da otite parasitária bovina causada por

1 Received on May 29, 2009.

Accepted for publication on July 9, 2009.

2 Departamento de Parasitologia Animal, Instituto de Veterinária, Universidade Federal do Rio de Janeiro (UFRRJ), Rodovia BR $465 \mathrm{Km}$ 7, Seropédica, Rio de Janeiro $23890-000$, Brazil. *Corresponding author: gverocai@gmail.com

${ }^{3}$ Department of Ecosystem and Public Helth, Facult of Veterinary Medicine, University of Calgary, 3330 Hospital Drive NW Calgary, AB T2N 4N1, Canada

${ }^{4}$ Faculdade de Medicina Veterinária, Campus Castanhal, Universidade Federal do Pará, Rua Maximino Porpino 1000, Castanhal, PA 68743-080, Brazil.

${ }^{5}$ Empresa de Pesquisa Agropecuária do Estado do Rio de Janeiro (Pesagro-RJ), Rodovia BR 465 Km 7, Seropédica, RJ 23890-000, Brazil. nematóides rhabditiformes. Dezoito vacas Gir apresentando otite clínica foram divididas em três grupos de seis animais cada. O primeiro não recebeu tratamento (grupo controle). O segundo foi tratado com ivermectina "pouron" a $0,05 \%$ na dose de $500 \mu \mathrm{g} / \mathrm{kg}$ de peso vivo. O terceiro grupo foi tratado com sulfóxido de albendazol oral a $6 \%$ na dose $6,0 \mathrm{mg} / \mathrm{kg}$. Os condutos auditivos de todos os animais foram reexaminados nos dias 7 e 21 pós-tratamento. Os animais do grupo controle permaneceram infectados nos dias de observação. O tratamento com ivermectina não demonstrou eficácia alguma para os dias 7 e 21 pós-tratamento. $\mathrm{O}$ tratamento com sulfóxido de albendazol obteve 16,7 e $25 \%$ de eficácia nos dias 7 e 21, respectivamente. Mais estudos são necessários para determinação de tratamentos eficazes para tal doença parasitária, especialmente através de vias alternativas de administração, por causa de seu significante impacto na criação de Bos taurus indicus nas Regiões Tropical e Subtropical. 
TERMOS DE INDEXACAO: Otite parasitária bovina, nematóides rhabditiformes, Rhabditis sp., tratamento.

\section{INTRODUCTION}

Bovine parasitic otitis caused by rhabditiform nematodes has been reported in African countries with a warm and moist environment, such as Tanzania, Kenya and Zimbab-we, generating significant economic losses (Round 1962, Msolla et al. 1986, Ushewokunze-Obatolu et al. 1999). In Brazil, it was first described by Martins-Junior et al (1971), and ever since this disease has been reported in other States, such as Minas Gerais and Goiás (Leite et al. 1993, Vieira et al. 2001, Duarte et al. 2001) and, most recently in the States of Pernambuco (Brito et al. 2005) and Rio de Janeiro (Verocai et al. 2007). The breeds which are more prone to this disease are, Bos taurus indicus, Gyr and Indubrasil (a cross-breed of Gyr, Nellore and Guzerat). This is thought to happen because of the anatomical conformation of its external ear and ear canals, offering favorable growth conditions to the nematode because of the presence of organic secretions, heat and humidity. Severely affected animals are usually apathetic and without appetite, showing constant head movement. Clinical signs also include purulent and fetid otorrhea (which predisposes to myiasis) in addition to nervous symptoms such as facial hemiplegia, which profoundly affects food apprehension and mastication, thus drastically reducing weight gain (Msolla et al. 1993, Verocai et al. 2007). While in Africa the parasite was identified in most of the cases as Rhabditis bovis, in Brazil four different species were described parasitizing the ear canal of cattle, including $R$. freitasi e $R$. costai (Martins-Junior 1985). In Africa, there are reports of some effective treatments (Msolla et al. 1985, Msolla et al. 1987). The purpose of this study is to evaluate the efficacy of orally administred albendazole sulphoxide and pour-on ivermectin for the treatment of bovine parasitic otitis caused by rhabditiform nematodes.

\section{MATERIALS AND METHODS}

During a survey on bovine parasitic otitis on a farm located in Massambará District $\left(22^{\circ} 21^{\prime} \mathrm{S}, 43^{\circ} 34^{\prime} \mathrm{W}\right)$, Municipality of Vassouras, Rio de Janeiro State, Southeastern Brazil (Verocai et al. 2007), cows were diagnosed as positive for rhabditiform nematodes by the technique described by Leite et al. (1994). It consists in swabbing the ear canal and then depositing the sample in test tubes, individually. The nematodes can be observed on the tube's wall or bottom with the naked eye. Eighteen Gyr cows, belonging to the above mentioned farm with clinical otitis and positive for rhabditiform nematodes in both ear canals, were divided into three groups of six animals each. One group did not receive any treatment and was considered the control group. A second group was treated with ivermectin $0.5 \%$ pour-on (Puritec $($, Vetbrands Brasil Ltda, Santa Terezinha 303, Paulínia, SP), corresponding to a dose of $500 \mu \mathrm{g} / \mathrm{kg}$, and a third group was orally treated with albendazole sulphoxide 6\% (Ricobendazole Oral囚, Ouro Fino Agronegócio, Rodovia Anhanguera, SP 330, Km 298, Distrito Industrial, Cravinhos, SP).

Those drugs and administration routes were chosen because of they are widely used for control of gastrointestinal parasites in cattle and considered more practical and less harmful, respectively. Both ear canals of each animal were re-examined on days 7 and 21 post treatment, looking for the presence of living nematodes by the same technique used for the original diagnosis. The materials from the test tubes were also fixed in $70 \%$ alcohol solution, for further analysis under stereomicroscopy. The data were analyzed by the Fisher's Exact Test, performed using the Biostat 2.0 program (Ayres et al. 2005).

\section{RESULTS AND DISCUSSION}

The animals from the control group remained infected through the days of observation. The ivermectin group did not show any efficacy on days 7 and 21 after treatment. The albendazole sulphoxide treatment showed an efficacy of $16.7 \%$ and $25 \%$ on days 7 and 21 , respectively (Table 1). The visits were suspended after day 21 due to the unsatisfactory results. No statistical differences were

Table 1. Number of positive or negative ears for Rhabditis sp. infection from control and treated animals

\begin{tabular}{lcccccc}
\hline \multirow{1}{*}{ Groups } & \multicolumn{5}{c}{$\begin{array}{c}\text { Total of positive or negative ears } \\
\text { for Rhabditis infection }\end{array}$} \\
\cline { 2 - 7 } & \multicolumn{5}{c}{ Day 0} & \multicolumn{2}{c}{ Day 7} & \multicolumn{2}{c}{ Day 21} \\
& + & - & + & - & + & - \\
\hline Control & 12 & 0 & $12^{\mathrm{a}}$ & 0 & $12^{\mathrm{a}}$ & 0 \\
Albendazole sulphoxide * & 12 & 0 & $10^{\mathrm{a}}$ & 2 & $9^{\mathrm{a}}$ & 3 \\
Ivermectin & 12 & 0 & $12^{\mathrm{a}}$ & 0 & $12^{\mathrm{a}}$ & 0
\end{tabular}

a Values followed by the same superscript letter in the same column are not significantly different $(p<0.05)$. *Ricobendazole Oral $₫$, oral, $6.0 \mathrm{mg} /$ kg. ${ }^{* *}$ Puritec $®$, pour-on, $500 \mu \mathrm{g} / \mathrm{kg}$.

observed between the treated and the other control groups $(p>0.05)$.

In the literature some treatments (mostly from Africa) show desirable efficacy, even though the occurrence of re-infections is extremely frequent. It is also important to highlight that besides the need for an effective control, treatment should be performed as soon as possible in order to avoid the appearance of nervous symptoms. In Africa, Msolla et al. (1985) obtained an efficacy of more than 95\% using subcutaneous ivermectin, combined with topical application of 2 to 3 drops of ivermectin 1\% into each infected ear. Msolla et al. (1987) also employed a $0.25 \%$ toxaphene hand spray, dip washes of $0.25 \%$ toxaphene with 2ppm nicotine extract twice a week for a period of 12 weeks, consecutively, with $95.3 \%$ efficacy, but this procedure was laborious. Odongo \& D'Souza (1989) suggest as an effective treatment topical administration of $10 \%$ triclorfon $-10 \%$ oxytetracycline solutions. In Brazil, some studies were performed regarding this type of parasitism. Leite et al. (1994) recommended flushing the ear canals with a 1:1 ether-ethanol (92-96 GL) solution containing $2 \%$ copper sulphate as treatment for clinical and subclinical bovine parasitic otitis. Although, this study did not include any efficacy data, the authors pointed out that efficacy was almost $100 \%$. Vieira et al. (2001) compared the treatment described previously with a second one, consisting of a single application of $3 \%$ 
triclorfon and $1 \%$ dimethylsulphoxide (DMSO) solution, using a nitrofurazone cream vehicle. Both protocols did not achieve the desirable effect when used in the ear canal under field conditions.

Topical treatments are more likely to be effective. However, the use of some anthelmintic drugs is strongly contraindicated into ear canals because it could lead to critical consequences by crossing the blood-brain barrier. Consequently, another route of administration (e.g. pouron, oral or injectable) should be considered safer and more practical when used with in outbreaks in large herds. Studies related to alternative administration routes are necessary to assess the effective treatment for this parasitism because of its significant impact on cattle breeding in Tropical and Subtropical Regions.

Acknowledgements.- To CNPq and CAPES for partial financial support.

\section{REFERENCES}

Ayres M., Ayres-Junior M., Ayres D.L. \& Santos A.S. 2005. BioEstat 4.0: aplicações estatísticas nas áreas das ciências biológicas e médicas. Sociedade Civil Mamirauá/Imprensa Oficial do Estado do Pará, Belém. 324p.

Brito S.S., Lima M.M., Faustino M.A.G., Cavalcanti M.P., Ramos C.A.N. \& Alves L.C. 2005. Otite parasitária em bovinos na estação experimental João Pessoa (EEJP), Emepa, Paraíba. Ciênc. Vet. Trópicos 8(1):84-87.

Duarte E.R., Melo M.M. \& Hamdan J.S. 2001. Epidemiological aspects of bovine parasitic otitis caused by Rhabditis spp. and/or Raillietia spp. in the State of Minas Gerais, Brazil. Vet. Parasitol. 101(1):4552.

Leite R.C., Nunes V.A., Nunes I.J., Costa A.L., Faccini J.L.H. \& Lopes C.W.G. 1993. Otite parasitária por nematóides rhabditiformes: aspectos epidemiológicos e clínicos. Rev. Bras. Med. Vet. 15(2):49-51.
Leite R.C., Leite R.C. \& Faccini J.L.H. 1994. Diagnóstico e tratamento da otite parasitária por nematóides rhabditiformes em bovinos. Revta Bras. Parasitol. Vet. 3(1):69-70.

Martins-Junior W., Nunes I.J., Ribeiral L.A., Rosaz C.E.F. \& Nunes V.A. 1971. Nota sobre a ocorrência de Rhabditidae (Nematoda, Rhabditida) relacionados com otite em bovinos na região geo-econômica de Brasília, DF. Ciência e Cultura 23(Supl.):248-249.

Martins-Junior W. 1985. Rhabditis (Rhabditis) freitasi sp.n. e Rhabditis (Rhabditis) costai sp.n. (Nematoda-Rhabditidae) isolados de otite bovina. Mem. Inst. Oswaldo Cruz 80(1):11-16.

Msolla P., Falmer-Hansen J., Musemakweli J. \& Monrad J. 1985. Treatment of bovine parasitic otitis using ivermectin. Trop. Anim. Health Prod. 17(3):166-168.

Msolla P., Matafu E.P.M. \& Monrad J. 1986. Epidemiology of bovine parasitic otitis in Tanzania. Trop. Anim. Health Prod. 18(1):51-52.

Msolla P., Mmbuji W.E.O. \& Kassuku A.A. 1987. Field control of bovine parasitic otitis. Trop. Anim. Health Prod. 19(1):179-183.

Msolla P., Semuguruka W.D., Kassuku A.A. \& Shoo M.K. 1993. Clinical observations on bovine parasitic otitis in Tanzania. Trop. Anim. Health Prod. 25 (1):15-18.

Odongo M.O. \& D'Souza C.F. 1989. Prevalence and treatment of bovine parasitic otitis in Olkarkar group ranch of Kajiado district, Kenya. Bull. Anim. Health Prod. Afr. 37:191-194.

Round M.C. 1962. The helminth parasites of domesticated animals in Kenya. J. Helminthol. 36(4):375-449.

Ushewokunze-Obatolu U., Pfukenyi D.M. \& Ushe T. 1999. A retrospective epidemiological study of parasitic otitis in cattle in the South-East Lowveld of Zimbabwe. Zimbabwe Vet. J. 30(1):19-24.

Verocai G.G., Fernandes J.I., Correia T.R., Melo R.M.P.S., Alves P.A.M. \& Scott F.B. 2007. Otite parasitária bovina por nematóides rhabditiformes em vacas Gir no Estado do Rio de Janeiro. Revta Bras. Parasitol. Vet. 16(2):105-107.

Vieira M.C.M., Silva L.A.F., Araújo J.L.B., Andrade M.A., Fioravanti M.C.S. \& Silva E.D. 2001. Otites parasitárias por nematóides rabditiformes em bovinos: avaliação de tratamentos. Ciênc. Anim. Bras. 2(1):51-55. 